\title{
Assessment of Organic Farmers' Knowledge and Adaptation Strategies to Climate Change and Variability in Central Kenya
}

Ndukhu, O; Onwonga, N; Wahome, G; Kironchi, G; Høgh Jensen, Henning

Published in:

British Journal of Applied Science and Technology

Link to article, DOI:

10.9734/BJAST/2016/16270

Publication date:

2016

Document Version

Publisher's PDF, also known as Version of record

Link back to DTU Orbit

Citation (APA):

Ndukhu, O., Onwonga, N., Wahome, G., Kironchi, G., \& Høgh Jensen, H. (2016). Assessment of Organic Farmers' Knowledge and Adaptation Strategies to Climate Change and Variability in Central Kenya. British Journal of Applied Science and Technology, 17(6), 1-22. [16270 ]. https://doi.org/10.9734/BJAST/2016/16270

\section{General rights}

Copyright and moral rights for the publications made accessible in the public portal are retained by the authors and/or other copyright owners and it is a condition of accessing publications that users recognise and abide by the legal requirements associated with these rights.

- Users may download and print one copy of any publication from the public portal for the purpose of private study or research.

- You may not further distribute the material or use it for any profit-making activity or commercial gain

- You may freely distribute the URL identifying the publication in the public portal 


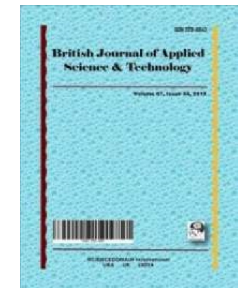

British Journal of Applied Science \& Technology

17(6): 1-22, 2016, Article no.BJAST.16270

ISSN: 2231-0843, NLM ID: 101664541

SCIENCEDOMAIN international

www.sciencedomain.org

\title{
Assessment of Organic Farmers' Knowledge and Adaptation Strategies to Climate Change and Variability in Central Kenya
}

\author{
O. H. Ndukhu ${ }^{1 *}$, N. R. Onwonga ${ }^{1}$, G. R. Wahome ${ }^{1}$, G. Kironchi ${ }^{1}$ \\ and H. H. Jensen ${ }^{2}$ \\ ${ }^{1}$ University of Nairobi, Kenya. \\ ${ }^{2}$ Technical University of Denmark, National Food Institute, Denmark.
}

Authors' contributions

This work was carried out in collaboration between all authors. Author OHN designed the study, performed the statistical analysis, wrote the protocol, wrote the first draft of the manuscript and managed literature searches. The rest were supervisors. All authors read and approved the final

manuscript.

Article Information

DOI: $10.9734 / B J A S T / 2016 / 16270$

Editor(s):

(1) Xu Jianhua, Department of Geography, East China Normal University, China.

Reviewers:

(1) Ahmed Karmaoui, Cadi Ayyad University, Morocco.

(2) Bruce Kelly da Nobrega Silva, Federal University of Rio Grande do Norte, Brazil. Complete Peer review History: http://www.sciencedomain.org/review-history/16838

Original Research Article

Received $20^{\text {th }}$ January 2015 Accepted $8^{\text {th }}$ March 2016 Published $8^{\text {th }}$ November 2016

\begin{abstract}
A survey was carried out to determine the causes of low vegetable production by looking at the challenges faced by organic based smallholder farmers and the potential coping strategies employed and their experiences, coping and adaptation strategies to climate change and variability $(\mathrm{CCV})$. The study's objective was to determine the major vegetables grown, marketable quality attributes, challenges faced and coping strategies to enhance vegetable production and understanding of CCV. More than 60 organic based farmers from Kajiado, Kiambu and Murang'a counties of Kenya were selected for the survey through questionnaires. The data collected was analysed using SPSS. The challenges faced in production of the key vegetables included; unpredictable rains $85 \%$, lack of irrigation equipment $43 \%$, crop pests and diseases $28 \%$, among others. Causes of CCV cited were; deforestation and poor agricultural practices (62\%) and emission of green house gases (33\%). Effects of climate change were $(80 \%)$ reduced crop yields.
\end{abstract}


Ninety percent of farmers' responded to the effects of CCV through good agricultural practices such as; agro-forestry, mulching, organic inputs, drought tolerant crops and rain water harvesting. The farmers contended that through trainings and exposure, they would be empowered to cope with and reverse the negative impacts of CCV and consequently guarantee food and nutritional security. In addition, research efforts ought to be directed towards soil analysis, irrigation and greenhouse production and recommendations on site specific input rate application made available to the farmers.

Keywords: Challenges; climate change and variability; crops; organic farmers.

\section{INTRODUCTION}

Formal organic agriculture in Kenya dates back to the early 1980 s when the first pioneer organic training institutions were established [1]. Certified organic farming in Kenya is mostly geared to products destined for export with the large majority being exported to the Europe, which is Africa's largest market for agricultural produce [2]. The produce with the greatest demand are horticultural crops and most specifically vegetables. Consumer demand for organic vegetables has increased tremendously due to a number of reasons such as food safety, environmental concerns, flavour and freshness of the produce, health benefits and nutritional value [2]. Many African farmers mix long-tested traditional practices with adaptations of conventional technologies that suit their farming systems and these types of systems blend themselves well to conversion to organic agriculture [3]. However, new processes and production guidelines are required in many cases [4] to keep up to the standards of the quantity and quality of produce reaching the markets through better understanding of impacts of climate change.

The issue of climate change and variability (CCV) is a challenge to agricultural production in Kenya as the country's gross domestic product (GDP) normally mirrors rainfall pattern. Climate change is therefore a major impediment to agricultural production particularly and thus a threat to achieving millennium development goal number one (MDG 1) of eradicating extreme poverty and hunger [5]. The anticipated impacts of climate change will manifest in the form of floods, storms, prolonged droughts and increased atmospheric temperature [6]. The consequences will have far reaching adverse impacts on human health, food security, economic activities, physical infrastructure, natural resources and the environment [5]. The advancement of research on CCV and its impacts on agriculture has played a key role in development of both tactical and strategic means to buffering the impacts associated to it. However, less emphasis has been put on farmer's perception, experience and adaptation strategies as a basis for informing development of sustainable approaches to minimize the risks imposed by climate change and variability [7] especially so on organic farming.

The organic agriculture sector in Kenya has therefore mainly developed without any formal government policy support. The sector has consequently encountered a wide range of challenges during the last two decades. It is for this purpose that a survey was carried out to determine the specific quality attributes, challenges and coping strategies that the farmers face and find possible solutions which will create an influx in production and hence create food security to the organic consumer. In addition, this study intended to assess farmers' perceptions, experiences, and adaptation strategies with a view of enhancing and prioritizing the farmers' preparedness to minimize the effects of CCV.

\section{MATERIALS AND METHODS}

\subsection{Site Description}

The survey was carried out around Nairobi in central Kenya in the counties of Kajiado, Kiambu and Murang'a between $1^{\text {st }}$ and $4^{\text {th }}$ of February 2012. These are areas where organic cultivation of vegetables is prevalent due to awareness created there by Kenya Organic Agriculture Network (KOAN). Kajiado is categorized under agro-ecological zone IV [8]. Kiambu and Murang'a counties are categorized under agroecological zone III [8]. The main economic activities in Kajiado County are pastoralist livestock herding, tourism, agricultural cropsvegetables, cereals and pulses and urban-life activities like cattle trading, whereas in Kiambu and Muranga, dairy cattle, coffee and tea farming are predominant [9]. The food crop patterns are 
dominated by production of; vegetables, maize, beans, potatoes in a mixed intensive cultivation [10].

\subsection{Study Approach}

The study area had 108,358 households [11]. Among these 63 were listed in KOAN register (2012) as smallholder organic farmers all of whom were interviewed by trained enumerators. The respondents were visited on their farms on appointment after sensitization by KOAN field workers. A questionnaire (Appendix 1) was used to gather information on knowledge (i.e. challenges, causes and effects of CCV and adaptation strategies (i.e. change cropping systems, introduction of new technologies).

\subsubsection{Questionnaire administration}

To ensure that the questionnaire accurately captured the intended information, it was subjected to review by experts, supervisors and peers. The questionnaires were pre-tested by interviewing twenty (20) organic farmers on the first day. The content and clarity of questions of the questionnaires were checked and necessary corrections effected. Each of the five enumerators was assigned an average of three farmers a day.

\subsection{Data Analysis}

The collected data was entered into a spreadsheet and analyzed using Statistical Package for the Social Sciences (SPSS) for Windows version 17.02 [12]. Descriptive statistics and proportions were calculated for key categories.

\section{RESULTS AND DISCUSSION}

\subsection{Demographic Information}

The majority $(66 \%)$ of the farmers practicing organic farming were females compared to $(34 \%)$ males (Table 1). This may be attributed to the fact that women are being empowered by government and non-governmental organisations to engage in enterprises, such as organic farming to enhance their economic wellbeing.

Women were found to be organized into self-help groups and received funding from government and nongovernmental programmes. Thus most women make their own decisions on safe farming practices, healthy and productivity for their families. These findings corroborate those of Foeken and Owuor [13], who found that the majority of urban farmers are women. In Kenya over 70 per cent of agricultural activities are undertaken by women, especially in the smallscale producer sector. Similarly Grolink [10] and Taylor [14] found that on a small scale, women mainly undertake the production, sometimes primary processing, and the marketing of organic produce/products at the national level. Smallholder management is, in large part, in the hands of men while a great deal of the farming work is executed by women. Grolink [10] argues that, due to these inequities, social and economic development in Tanzania has been, and continues to be, uneven. In Kenya, the possibilities offered by organic farming are particularly appealing to women. They offer the possibility of successfully securing food for the family, without having to depend on cash or potentially dangerous chemical products according to Chavas et al. [15]. As a result, organic agriculture has begun to develop in densely populated areas on small holdings where food crops are grown intensively. Urban and peri-urban organic production provides food to vulnerable groups.

Table 1. Characteristics of the households in the study area

\begin{tabular}{lll}
\hline Demographics & Description & $\begin{array}{l}\text { Proportion } \\
\text { (\%) }\end{array}$ \\
\hline Gender & Male & 34 \\
Age & Female & 66 \\
& Below 30 & 7 \\
& $31-40$ & 21 \\
& $41-50$ & 11 \\
& $51-60$ & 28 \\
Level of & $61-70$ & 30 \\
education & 71 and above & 3 \\
& Primary & 16 \\
& Secondary & 36 \\
Source of & Post & 30 \\
income & secondary & \\
& University & 18 \\
& Farming & 62 \\
& & \\
& Business & 28 \\
& Employed & 10 \\
\hline
\end{tabular}

Women in the region are in general more prone to poverty and unemployment. Likewise, Darnhofer et al. [16] reported that organic agriculture projects and others in the region adopt a policy of promoting women and employing them in various operations. Almost 100 per cent of casual labourers in various 
processing operations are women. This stance has tremendous impact on the social status of women in communities and is an added input for the poverty reduction policy of the region which can improve family livelihoods according to Taylor [14]. Uganda has over 39,000 households certified as organic, the majority of which have organic cash crops as their major source of income. In this regard, commercial organic agriculture can be seen as an important source of employment and an employment opportunity especially for women [15].

In Argentina a model of organic orchards has been experimented to promote employment and food self-sufficiency especially for women, since the beginning of the 1990s. An NGO (proHuerta), with institutional support of the Secretariat for Social Development and other Government agencies, sought alternatives to improve the nutritional status (both quality and variety of food) of rural and urban populations and to create employment opportunities. This project benefited by 1996 nearly two million individuals, namely unemployed, indigenous, and food-insecure persons such as female-headed families, elders and under-aged according to Scialabba [17]. The initiative promoted small-scale food production by providing capacity-building, technical assistance, development and validation of alternative technologies, inter-institutional coordination, and provision of critical inputs [17]. In Costa Rica health motivations led to the formation of small-farmer groups to produce organic vegetables, which have been successfully marketed nationally over the last ten years. Agro-chemical price increase, soil exhaustion, health hazards, and growing alternative markets motivated producers to convert to organic production [18]. A study by Saito et al. [19], concluded that in most parts of Africa, women have traditionally been responsible for household food provision and farming is relatively easy to combine with the care of children.

Majority $(61 \%)$ of the organic farmers were aged over 50 years whereas $32 \%$ of them were between 31 and 50 years old (Table 1). This observation could be related to the fact that the youth mainly seek white collar jobs in the urban centres, leaving behind the elderly to engage in farming. Similarly the retired and elderly take up farming as a means to continue generating income and a hobby. According to Zelinski [20], the reasons why the elderly and retirees engage in farming include; that it may provide a purpose and structure and intellectual stimulation, conquer boredom and work environment provides more social interaction than staying at home. The elderly practise smallholder farming as a livelihood strategy in an effort to supplement their pensions according the findings of FAO [21]. According to surveys in the US by Kirkpatrick [22] of those respondents who planned to retire, a majority of them (55\% in lowa and $60 \%$ in Wisconsin) did not plan to move from their current home. The retiring generation consider their ability to truly relinquish control of the farm if they are living in the farmhouse, watching the daily activities and judging the successors' decisions. The desire to remain in the family home is natural, and this natural desire must be balanced with the needs of the business to not only continue but to thrive for the next generation.

A significant number (84\%) of farmers had a secondary level education and higher whereas $16 \%$ obtained primary education (Table 1 ). This implies that farming is appealing to the elite in the society as an alternative to white collar jobs and a means of supplementing income from other sources. This goes to stress the fact that organic based farming is being embraced by people who can comprehend the significance of this particular method of farming. A majority $(62 \%)$ of the farmers (mostly of retired civil servants) generated their income solely from farming, $28 \%$ businesses while $10 \%$ were in full time employment while practicing farming in their off-work hours (Table 1). These findings show that farming can on its own act as a steady source of income. Scialabba, [17] found that developing countries' farmers easily adopt organic techniques because they are close to their traditions and culture. The growth in the number of NGOs in agricultural development, particularly organic agriculture efforts, has proceeded to an especially impressive degree in Kenya. National and local NGOs dominate nearly all aspects of organic agriculture promotion, training, research, extension, and marketing according to Shrum [23]. A number of researchers; Farrington et al. [24], Wellard and Copestake [25] and Shrum [23] reported that, for the past two decades, indigenous NGOs have been promoting environmentally, economically, and socially sustainable agricultural alternatives to high external input (Green Revolution-GR) agriculture to the rural poor throughout Africa, Asia, and Latin America. National and local NGOs have played a significant role in organic 
agriculture promotion, training, research, and outreach since the 1980s.

Educational messages to promote organic foods need to consider psychographics, including personal values. Such messages could be tailored to appeal to people, particularly women, with strong environmental values. As Schwartz and Inbar-Saban [26] found out, one method of altering people's behaviour via their beliefs and values is values self-confrontation. This technique aims to modify behaviour by changing the priority of the values that lie beneath the behaviour. It has been used successfully to increase weight loss [26], decrease smoking rates [27], enhance pro-environment behaviour [28], and alters beliefs about meat, fruit and vegetables [29]. Participants in the latter study altered their beliefs and increased their consumption of fruits and vegetables when confronted with the results of a previous study that suggested that hierarchy and dominance are positively associated with meat, but negatively associated with fruit and vegetables [29]. It is therefore possible that this educational tool (values self-confrontation) could be used to alter beliefs about organic foods and consumption of organic foods. Similarly, Grube et al. [30] asserted that, values self-confrontation has been used through the mass media and therefore has the potential to reach large numbers of people.

\subsection{Crops Grown by Organic Farmers}

Most of the farmers surveyed produced kales $(63 \%)$, followed by spinach (32\%), tomatoes $(21 \%)$ and $(18 \%)$ maize (Fig. 1$)$.

This study shows that kale was the most popular vegetable produced because of high demand in the urban and peri-urban areas of which the study area are neighbouring. This corroborates with a study in Kiambu County by Salasya [31], which also found kale as a popular green vegetable consumed in most households in urban and peri-urban in Kenya. This was attributed to it being a major source of cash and having highest returns to variable inputs among other crops. Mose et al. [32] also reported that, in Kenya, kale vegetable is popular in many smallholder households because it is consumed together with maize, the staple food for majority of the citizens in both urban and peri-urban areas. According to; Ngigi et al. [33] and Torquati et al. [34], in contrast to urban agriculture, which is to be found within a town, city or metropolis, the places for peri-urban agriculture are on the fringe of a metropolis, a city or a town. The periurban area has also been described as a blended area with urban and rural landscape interests competing with each other. The periurban area is the interface between the highly complex urban area and the more uniform rural landscape area, mainly built on an agricultural economy with similar land use and community values according to Mackenzie et al. [35]. The increasing urban populations are thus turning into peri-urban populations and need more food and housing. In fact urban and peri-urban agriculture produces the majority of the perishable goods (e.g. vegetables, fruits, flowers etc.) consumed and used by the urban population. Thus, livelihood opportunities for urban and peri-urban farmers are generated $[33,34]$. Furthermore, peri-urban farming contributes to the growing, processing and distribution of a diversity of food and non-food products. Peri-urban agriculture reuses largely human, material resources and products and provides products for input suppliers, traders and other service providers, thereby adding value in the supply chain as reported by IWMI [36] and Scott et al. [37]. Maize, a predominant food crop in the country, is produced by less than $20 \%$ of the interviewed farmers. Duflo et al. [38], attributed this to the fact that most of the respondents were small holder farmers owning less than half an acre of land to economically produce the crop. Thus, they engaged in production of high value crops (vegetables) to take advantage of the ballooning city population.

\subsection{Marketable Quality Attributes Sought by Vegetable Consumers}

Nearly $76 \%$ of the farmers reported that consumers mostly look for clean and free of pest and disease signs, over $50 \%$ mentioned size, $35 \%$ colour while $14 \%$ cited texture as marketable quality attributes that are sought in a produce/vegetable before buying it (Fig. 2). Consumers consider absence of pest and disease attacks and physical damage as the best sign that the produce is of high quality. The demand for bigger cleaner kale could be because consumers regard them as a direct reflection on the farming practices and thus health and safety of the produce. Though size is mostly a characteristic of the specific kale variety, soil and environmental factors may contribute to size of kale leaves. 


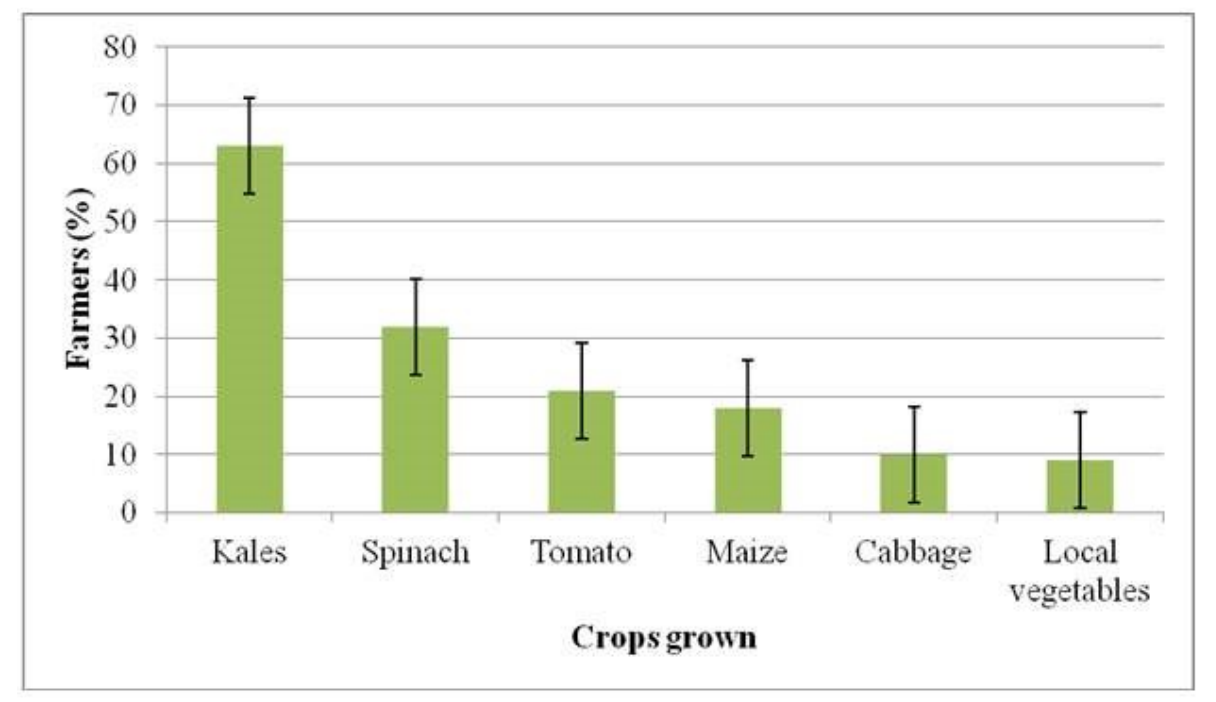

Fig. 1. Major high value crops grown by smallholder organic farmers

In their production therefore, the farmers paid keen attention to produce disease and pest free products. This was attributed to practicing organic based techniques such as planting certified seeds, early planting, use of biopesticides and also incorporation of pest repellent crops in the cropping systems. Welldrained loamy soils relatively high in organic matter are suitable. Phelan et al. [39] suggested that, reduced susceptibility to pests and diseases in organic farming may be a reflection of differences in plant health, as mediated by soil fertility management. These findings corroborate those of Okello and Swinton [40], who reported that, the demand for produce with specific physical attributes such as; colour, shape, size and spotlessness by consumers has encouraged farmers to produce with these attributes in mind. Consumer concerns about the safety of vegetables such as kale arise from the increase in food borne illnesses, thus raising the need to address food safety.

According to Scialabba [17], many NGOs have actively promoted organic agriculture in India. Growing environmental consciousness and fears of health hazards of conventional food has spawned domestic consumption of organic food. Similarly, expansion of domestic markets is leading to the surge of organic producers attracted by premium prices. Findings from analyses of the agro-economic performance of organic farming techniques compared to their conventional equivalents suggest that organic agriculture may be a viable and sustainable option for Kenyan smallholders, especially in areas of low or medium agricultural potential, according to; der Werf et al. [41], Diop et al. [42] and Onduru et al. [43]. Kenya Institute of Organic Farming (KIOF) and ETC-Netherlands researchers, employing matched pairs of organic and conventional farms, found that the use of compost, double dug beds, and liquid manure for maize production in medium-potential areas outperformed conventional practices in terms of maize grain yields, new cash benefits, return to capital, and return per family labour as reported by; der Werf et al. [41] and Diop et al. [42].

Similarly, Dimitri and Greene [44] found that, the use of organic farming techniques to grow crops has gained in popularity in recent years as a result of both an increase in consumer demand for organically grown produce and a genuine desire on the part of many growers to sustain or improve the soil. Oberholtzer et al. [45] asserted that, organic produce generally commands a higher price than conventional one, prompting producers to grow crops organically. The increased consumer demand appears to be driven primarily by the perception that organically grown produce is safer and more nutritious to eat than produce grown conventionally, according to; Lockie et al. [46] and Williams and Hammitt [47]. Iheke [48] also found out that, there was a rise in the production of vegetables globally, stimulated by high public demand, driven in large part by enhanced consumer awareness of the dietary and health benefits of fresh vegetable consumption. 


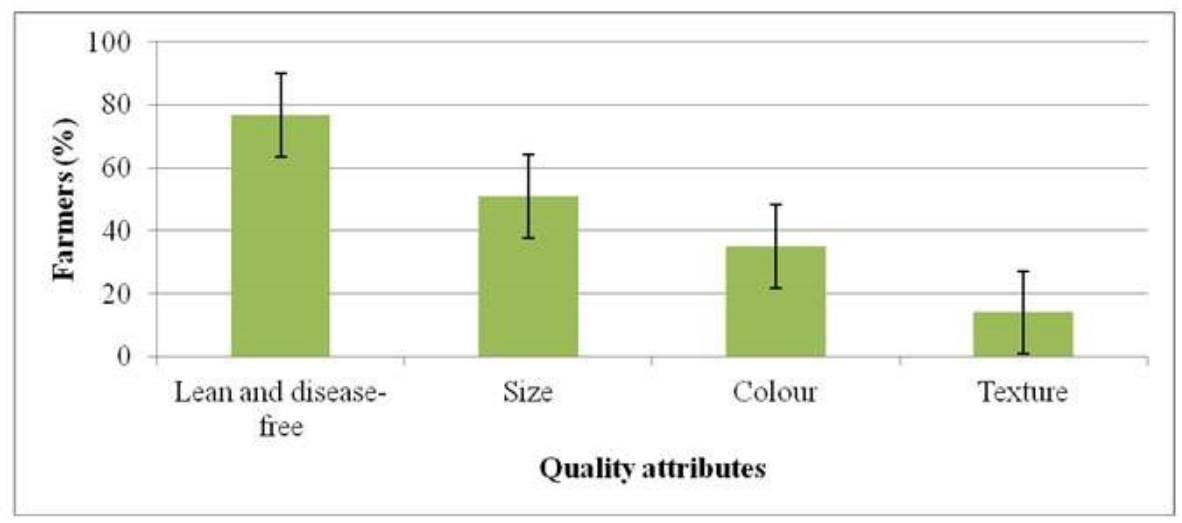

Fig. 2. Kale quality attributes that farmers produce for the market

\subsection{Challenges and Constraints of Organic Vegetable Production}

The biggest challenge farmers faced in production of kale and other key vegetables was unpredictable rains $(85 \%)$, followed by inadequate knowledge on input application rates $(66 \%)$, lack of irrigation equipment (43\%), inaccessibility to proper soil testing and analysis facilities $(37 \%)$ and $(28 \%)$ crop pest and diseases (Fig. 3). Changes and variability in climate in terms of rainfall and temperature affect crop productivity as well as pest and disease prevalence and incidences. Lack of knowledge on irrigation and soil fertility status may result in poor crop production. The challenges of rainfall delays and occasional erratic thunderstorms cause damage to crops and this is reflected in losses to the farmers and food insecurity in the country at large. These results corroborates those of a study conducted by Foeken and Owuor [13] who showed that farmers faced various constraints such as irregular rainfall, drought, flooding, water logging, poor soils, pests and disease, and destruction of crops by animals. IPCC [6] noted that challenges of vegetable production include population pressure, problems associated with land use such as erosion/siltation and possible ecological consequences of land use change on the hydrological cycle. Similarly Bationo et al. [49] found that, in Kenya, low and declining soil fertility is a major constraint to crop production in smallholder farming systems.

However, a strengths, weaknesses, opportunities and threats (SWOT) analysis on the smallholder farming sector was undertaken by Bett and Freyer [1] and summarized the main challenges and opportunities in the sector as policy based. This is because the government though has put in place policies and legislation that protect farmers in general, no extension of such policies existed for organic based farmers. This group of farmers is covered in the broad grouping of the agricultural sector and thus the specific challenges they face which do not relate to other farming practices cannot be ably addressed. It is observed that small scale organic based farmers in Kenya are faced by difficulties in gaining access to formal credit, since they do not have the requisite collateral to obtain credit and also due to the fact that the financial institutions do not recognize the differences between organic based and conventional agriculture.

In Nigeria, vegetable farmers' yields are below global yields. These low yields according to Abdulrahman and Yahaya [50] are due to a decline in the unit output from the various agricultural inputs such as capital, land, labour and management. Other constraints according to them include; soil fertility decline, soil borne diseases and pests, inadequate planting materials, high cost of labour, labour intensive operations and marketing of the product. Abdulrahman and Yahaya [50] in their study revealed that vegetable production is constrained by high cost of labour and labour intensive operations. Unreliable weather patterns and limited knowledge on appropriate inputs are the major challenges facing smallholder organic farmers.

\subsection{Coping Strategies Adopted by Farmers in Response to the Challenges of Organic Vegetable Production}

Most farmers $(76 \%)$ reported use of manures, mulches and ashes (76\%) as a coping strategy to challenges of crop production followed by 
blanket recommendations (74\%), irrigation $(64 \%)$, mass application of inputs $(55 \%)$ and (32\%) late planting (Table 2 ).

Adoption of organic based soil fertility management strategies such us use of manures, mulches and ashes is a good strategy by farmers in response to the challenges of organic vegetable production. Similarly, FAO [9] reported that, changes in crop planting schedules, management practices and varieties used, as well as the diversification of crops planted, are all low-cost options for reducing agricultural risk, which could be widely promoted through extension services and communication campaigns. Careful screening of these strategies and participatory action-oriented research with farmers will be needed to jointly identify and implement adaptation options that are feasible and effective and to ensure that these strategies do not have any negative or unexpected impacts on farmer livelihoods according to $\mathrm{FAO}$, [9] and Howden et al. [51]. Low-cost opportunity for policymakers and donors to invest in small-scale infrastructure, such as improved irrigation systems or crop storage facilities, which can help farmers to increase production and better protect their harvests, is vital. In the same token, USAID [52] and World Bank, [53] recommended that, governments and organizations working in vegetable production areas should seek to further promote such small-scale infrastructure through the development of small-scale grants and credit to farmers or farmer associations.

\subsection{Perceived Causes of Climate Change and Variability}

Above $62 \%$ of the farmers mentioned deforestation and poor agricultural practices
(PAPs) such as; monocropping, burning of crop residues and excessive application of synthetic agrochemicals, while over $33 \%$ reported emission of green house gases (GHGs) as major causes of CCV (Fig. 4). Factors that cause climate change can be divided into two categories - those related to natural processes and those related to human activity. The Earth's climate can be affected by natural factors that are external to the climate system, such as changes in volcanic activity, solar output, and the Earth's orbit around the Sun. Human activities, such as the burning of fossil fuels and the conversion of land for forestry and agriculture also cause climate change. According to a report by NAS [54], since the beginning of the Industrial Revolution, human influences on the climate system have increased substantially. Similarly, a report by IPCC [55] stated that the dominant product of fossil fuel combustion is carbon dioxide, a greenhouse gas.

The overall effect of human activities since the Industrial Revolution has been a warming effect, driven primarily by emissions of carbon dioxide and enhanced by emissions of other greenhouse gases. There is a scientific consensus that concentrations of greenhouse gases in the atmosphere are increasing and that this is causing global climate change according to IPCC [56] and NAS [54]. Human-driven emissions of carbon dioxide and other greenhouse gases, as well as land-use change, are the processes primarily responsible for the increase. Solomon [55] urged that, water vapour $\left(\mathrm{H}_{2} \mathrm{O}\right)$ and carbon dioxide $\left(\mathrm{CO}_{2}\right)$ are the two largest contributors to the greenhouse effect. Methane $\left(\mathrm{CH}_{4}\right)$, nitrous oxide $\left(\mathrm{N}_{2} \mathrm{O}\right)$, chlorofluorocarbons (CFCs) and other greenhouse gases are present only in trace amounts, but can still have a powerful warming

Table 2. Coping strategies adopted by farmers in response to the challenges faced

\begin{tabular}{lll}
\hline Challenges & Coping strategies & $\%$ \\
\hline Unreliable rainy season & Irrigation & 64 \\
Knowledge on soil input application & Late planting & 32 \\
& Mass application & 55 \\
Access to soil fertility and nutrient analysis & Indigenous techniques-use of manures, & 45 \\
& mulches and ashes & 74 \\
& Blanket recommendations & 28 \\
Pest and disease management & Outdated information - rates advised by & 11 \\
& government extension agents in the last & 76 \\
& decades to the farmers still in use presently & 13 \\
\hline
\end{tabular}




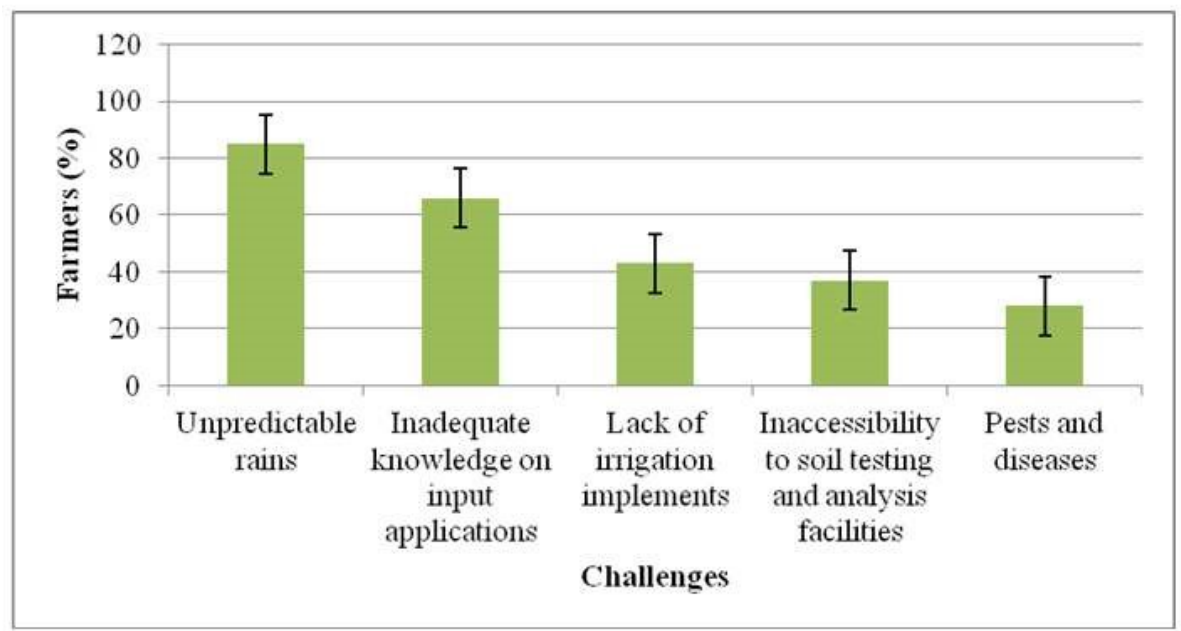

Fig. 3. Challenges and constraints of vegetable production by smallholder organic farmers

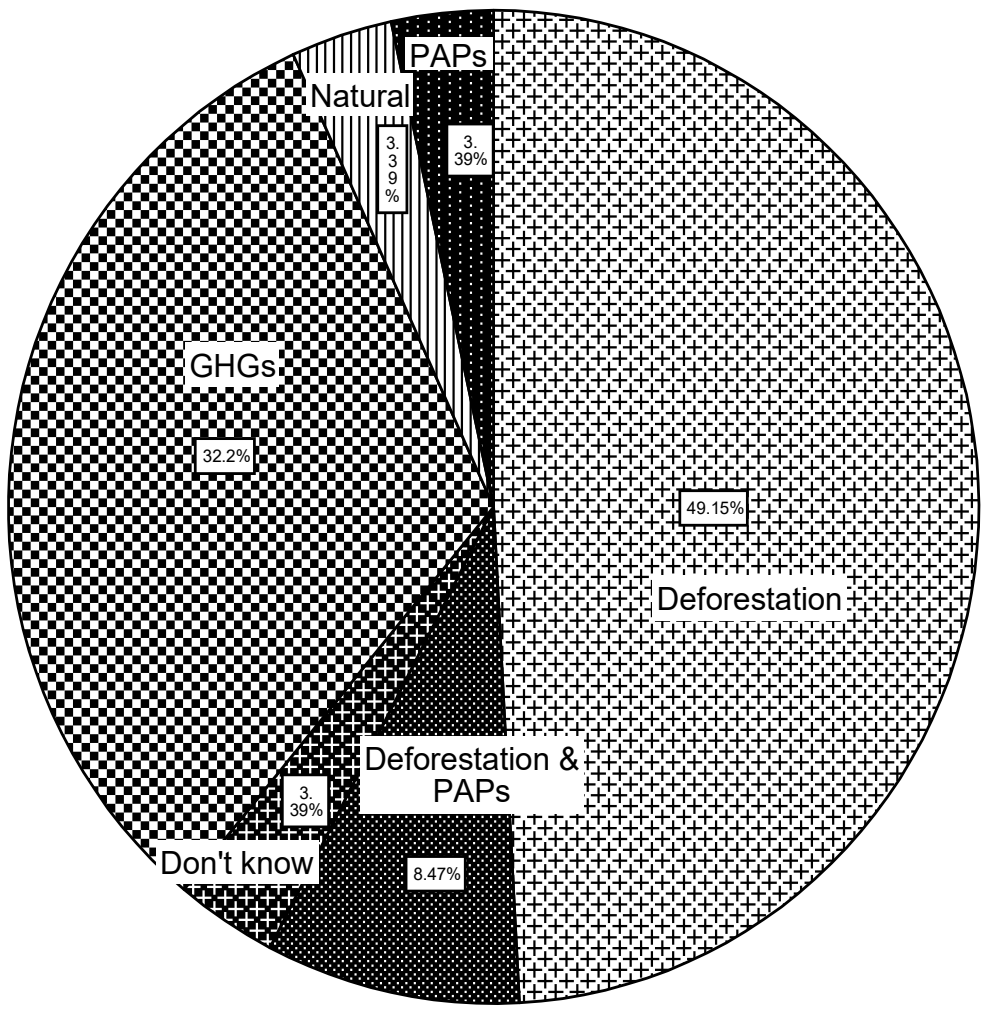

Fig. 4. Perceived causes of climate change and variability as per respondents

effect due to their heat-trapping abilities and their long residence time in the atmosphere. According to Solomon [55], the concentration of $\mathrm{CO}_{2}$ in the atmosphere in 2005 was 379 parts per million (ppm), compared with the pre-industrial value of $280 \mathrm{ppm}$, and is rising at $1.9 \mathrm{ppm}$ per year (1995-2005 average). The increase in concentration of greenhouse gases in the atmosphere has altered the earth's radioactive balance, resulting in more of the sun's heat being absorbed and trapped inside the earth's atmosphere, producing global warming. Without mitigation measures, the concentration of $\mathrm{CO}_{2}$ in the atmosphere is predicted to rise to at least 
$650 \mathrm{ppm}$ and up to $1200 \mathrm{ppm}$ by 2100 [56], which is expected to increase average global temperature by 1 to $6^{\circ} \mathrm{C}$. Most scientists agree that global warming caused by anthropogenic greenhouse gas emissions is one of the most serious environmental problems facing the world today, with far-reaching consequences for all sectors of society. To avert catastrophic impact it is generally agreed that atmospheric $\mathrm{CO}_{2}$ concentration should be constrained to $550 \mathrm{ppm}$, which is believed will limit the temperature increase to $2^{\circ} \mathrm{C}$.

\subsection{Techniques of Weather Forecasting}

More than $70 \%$ of the farmers were familiar with the scientific techniques of weather forecasting as presented by meteorologists, which they use to inform their farm management decisions whereas only $23 \%$ of them reported use of traditional methods of weather forecasting such as observation of the sky for either clouds or stars and movement of ants, birds, shading of tree leaves to herald onset of rains (Fig. 5). Scientific techniques of weather forecasting are reliable in these times of climatic changes hence more farmers adopt them as opposed to rudimentary traditional ones.

The reason for more and more reliance on the scientific weather forecasting techniques could be due to environmental degradation induced by the current CCV which has made non-routine and complex, the specific behavioural aspects of the plants and animals that were relied upon for weather forecasting. Similarly Luseno [57] found that, the application of traditional means of weather forecasting was on the decline. He attributed the decline in use of these techniques to the fact that it has become increasingly difficult for people to anticipate weather patterns, a situation some linked to CCV. Consequently credibility of these methods is suspect as they are subject to seasonal and/or yearly variation. According to Dunn [58], activities of arthropods, such as fleas, cockroaches, houseflies, spiders and many others are indications for the arrival of the summer season in Japan. Even the local names of invertebrates are figuratively indicative of a particular season. These arthropods have been noticed by farmers to be abundant during the summer season. Farmers for example stated that cockroaches disappear during winter season. Kihupi et al. [59], also observed that traditional climate prediction and contemporary seasonal predictions were both useful and dependable, by resource poor as well as commercial farmers. This system of indigenous knowledge leads farmers to participate as agents as well as consumers in programs that use modern climate science to plan for and adapt to climate variability and climate change as reported by Orlove et al. [60]. According to Ziervogel [61], provision and proper utilization of science-based agro-meteorological knowledge could guide farm level decisions on crop suitability, cultivar selection, choice of cropping systems, planting dates as well as planting densities.

\subsection{The Effects of Climate Change and Variability from Farmers Perspectives}

Reduced crop yields and/or crop failure were reported by $80 \%$ of the interviewed farmers as the most profound impacts of climate change and variability on agricultural productivity compared to $8 \%$ who indicated change in planting time and $6 \%$ mentioned increased crop pest and disease attack (Fig. 6). These impacts lead to a decline in farm production affecting incomes and food security. As the climate continues to change, there will be increased disturbance through more frequent extreme weather events, including severe storms, drought, tornadoes, hurricanes, and ice storms. Indirect effects may amplify these changes, with conditions that favour fire, insect and pathogen outbreaks, and invasive species.

This exacerbates hunger and poverty, contrary to the aspirations of the MDGs of halving extreme hunger and poverty by 2015 [5]. These observations imply that the more dependent a person is on agriculture as a source of income the greater the sensitivity to climate related changes. This observation is also in agreement with Grothmann and Patt [62] who noted that, the more one is likely to be affected by a given factor, the higher the attention given to it. The high rating of climate change by farmers who depended on farming solely as their source of income is therefore attributable to the fact that any factor, in this case climate change, that lowers crop production poses a threat to their livelihood hence considered a serious risk, which is also inconformity the findings of Grenzeback and Lukmann [63].

Pauchard et al. [64] also found that, disturbances such as fire, insect outbreaks, disease, drought, invasive species, and storms are part of the ecological history of most forest 
ecosystems, influencing vegetation age and structure, plant species composition, productivity, carbon (C) storage, water, crop yields, nutrient retention, and wildlife habitat. Climate influences the timing, frequency, and magnitude of disturbances, according to Dale et al. [65]. Climate change will alter the abiotic conditions under which plant species can establish, survive, reproduce, and spread, according to Alpert et al. [66]. Key environmental consequences of climate change are increased temperature, longer growing seasons, less snow, and more frequent drought. According to Allen and Breshears [67], these effects are expected to increase plant stress and decrease survival in the drier, warmer, and lower elevation portions of species' ranges. With climate change, however, new habitat, once too cold or wet, may become available, enabling plants to survive outside their historical ranges and expand beyond their current ranges. O'Gorman and Schneider and [68] Trenberth et al. [69] are also in agreement that, based on analysis of recent climate records and the projections of climate change simulations, hydro-climate extremes will become more prominent with a warming climate, (with potential increases in flood frequency, droughts and low flow conditions, saturation events, landslide occurrence, and erosion.

\subsection{The Challenges of Climate Change and Variability}

About $93 \%$ of the interviewed farmers had heard of and experienced the impacts of climate change, the common aspects being erratic and often inadequate rainfall $(83 \%)$ and raising air temperatures $(58 \%)$ whereas over $50 \%$ of them experienced climate variability through droughts (Fig. 7).

Most of these farmers recall the variations in the amounts and distributions of rains and daily temperature ranges of the past in comparison to the current period. Most of them felt that this change started to be evident more than was two decades ago. As a result of climate change, after every 1-3 years, $97.6 \%$ pointed out that air temperatures had increased and the start of rains had become unpredictable leaving $68.8 \%$ of the farmers guessing on the right time to plant in Mbeere, Mount Kenya region. This fact is also reinforced by Williams and Funk [71] and Markowitz [72] assertion that people's

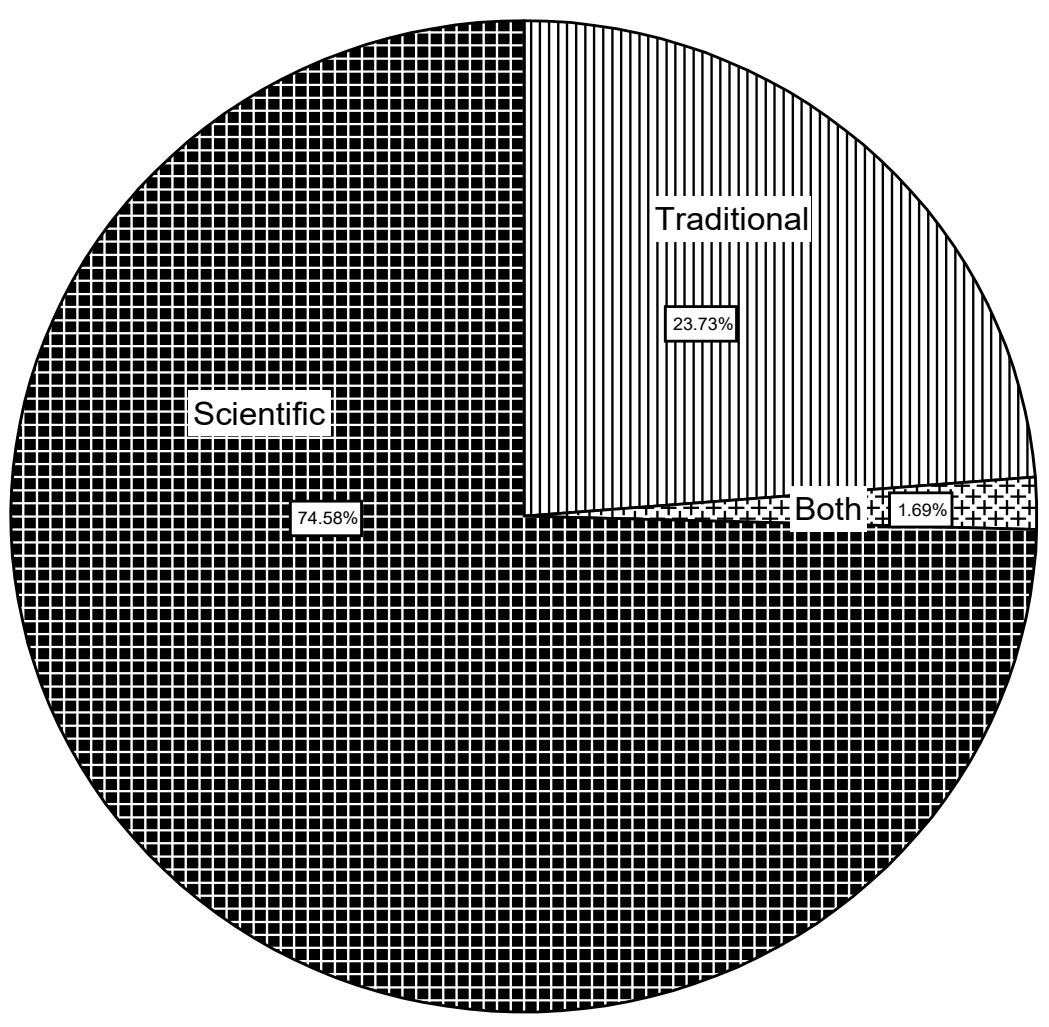

Fig. 5. Rating of weather forecasting methods by the respondents 


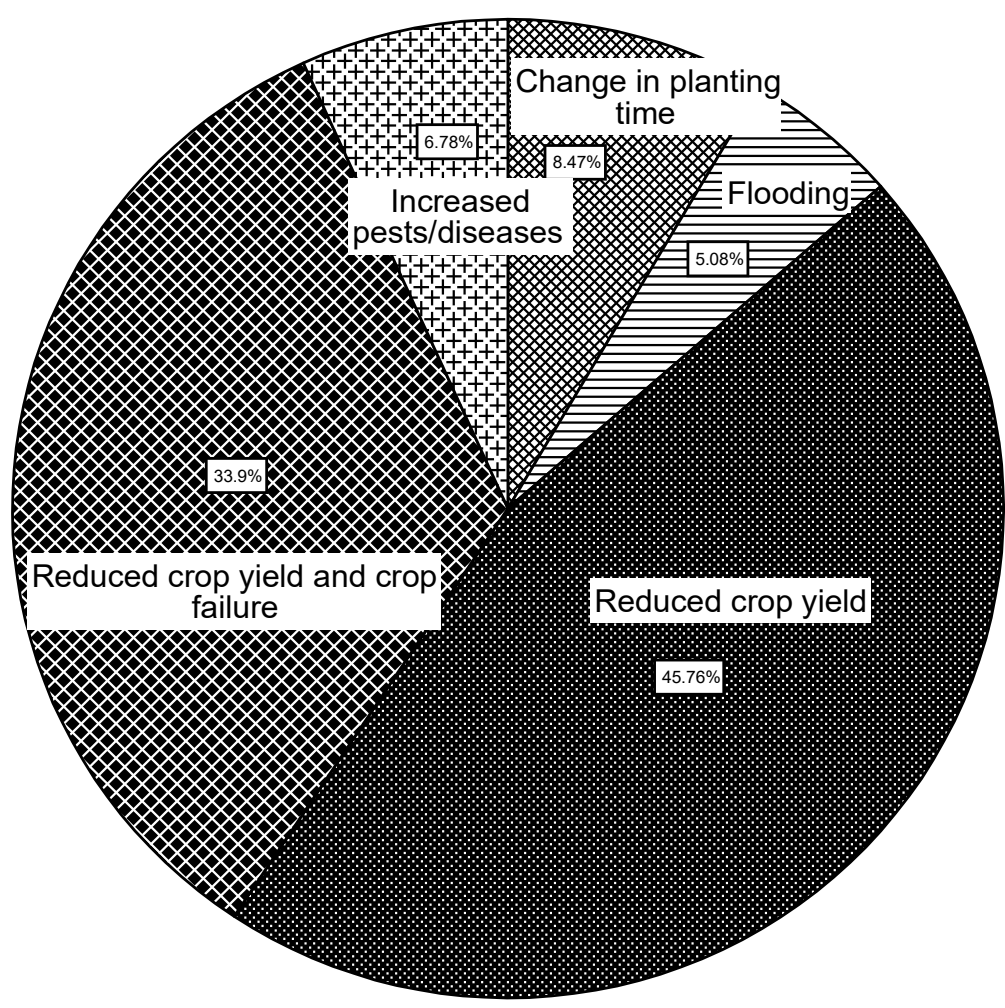

Fig. 6. Effects of climate change as perceived by organic farmers

perceptions of environmental risks suggest that people perceive little personal control over global and regional environmental problems. Thornton et al. [73] concluded that Eastern Africa is to face the impacts of climate change with temperatures only rising by $1{ }^{\circ} \mathrm{C}$ by 2030 and in general, rainfall increasing by 7 to $9 \%$ with a corresponding increase in length of growing season in many parts. Williams and Funk [71], in an analysis of East African rainfall data, suggest a decline in the long rains which they attribute to temperature increases in the Indian Ocean. Researchers have, however, warned that should climate change exacerbate current conditions, food production in Africa could decline and the range of infectious diseases could spread, according to Butt et al. [74]. In other words, the impacts of anthropogenic climate change on Africa at present and in the future are very much uncertain.

\subsection{Organic Farmers' Adaptation Strategies to Climate Change and Variability}

Good agricultural practices comprising; agroforestry, mulching, organic inputs, drought tolerant crops, legume intercrops and rain water harvesting as reported by about $90 \%$ of the farmers were the principal adaptation strategies with over $15 \%$ reporting afforestation (Fig. 8). Through farm planning and training on climate change and variability farmers will effectively cope with the effects of climate change and variability. These findings are in line with Kaloki's (2010) who deduced that almost all farmers interviewed $(98.5 \%)$ had adopted a new technology in the last 10 years. This was important because new interventions in the area meant adoption rates were high so long as the technologies are appropriate. The most important adaptation technique was early planting followed by planting drought tolerant crops and monocropping. By planting a sole crop, interspecific competition for water is limited hence crops could perform better. Use of manure to provide high plant vigour in the initial stages of growth was also identified as an important practice alongside planting early maturing crops [70]. Farmers have long been using plant and animal manures, but guidance on optimal timing, placement, and quantity was needed. 




Fig. 7. Aspects of climate change

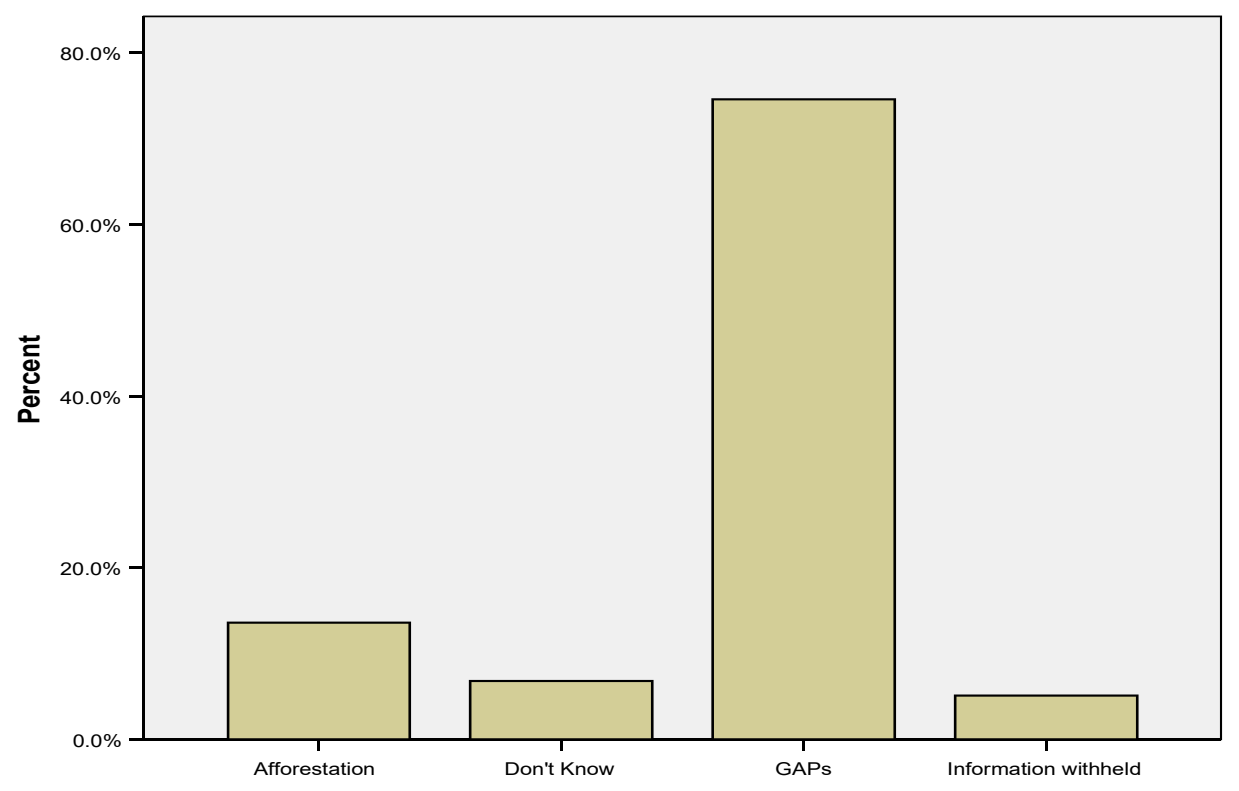

Which strategies do you use to response to current and/or anticipated effects of climate change?

Fig. 8. Organic farmers' adaptation strategies to CCV

Similarly Mihindo [75] reported that, intercropping and crop rotation are other traditional practices where science can support the traditional process of trial and error. To cope with these challenges, there is an urgent need to improve farmer extension services to provide technical 
information and training on the best management practices for planting, harvesting and crop storage, to facilitate the adoption of new management practices and to encourage farmerto-farmer learning. Madison [76] concurred that, strengthening extension services has been shown to be particularly effective at convincing farmers to change farming practices in response to climate change. Savings and loans groups in which members pool resources and lend to members in need are also a low-cost solution that could help to reduce the worst impacts of the extreme weather events, while creating local funds that farmers can tap into for other development activities, according to the findings by; Heltberg et al. [77] and Bhattamishra and Barrett [78].

\section{CONCLUSION}

It can be concluded that farmers were aware of the challenges, causes and effects of climate that and have embraced adaptation strategies to mitigate these impacts. In the same token, farmers know the challenges they in vegetable production and have adopted coping measures. Therefore, by availing knowledge of the challenges, causes and effects/impacts of climate change and variability to vegetable production and the existing coping strategies that farmers use, this study provides critical information for development organizations and donors focused on food security and poverty alleviation, as well as for policymakers working on the design of both national and international strategies for climate change adaptation, agricultural productivity, and hunger and poverty alleviation. Low-cost and local approaches such as revitalizing farmer extension services, implementing small-scale local infrastructure projects with farmers, strengthening informal safety nets and safeguarding natural ecosystems, could go a long way towards beginning to address this critical challenge and improving the livelihoods of smallholder farmers across the country. The survey sought to assess the causes of low vegetable production by looking at the challenges faced by organic based smallholder farmers and the potential coping strategies employed and their experiences and perceptions of climate change and variability.

\section{COMPETING INTERESTS}

Authors have declared that no competing interests exist.

\section{REFERENCES}

1. Bett KE, Freyer B. Recognizing and realizing the potential of organic agriculture in Kenya; 2007.

2. Helga W, Yussefi M. The World of organic agriculture. Statistics and Emerging Trends. IFOAM, Bonn; 2006.

3. Walaga C, Hauser M. Achieving household food security through organic agriculture? Lessons from Uganda. Journal für Entwicklungspolitik. 2005;XXI/3.:65-84.

4. Koepke N, Baten J. Climate and its impact on the biological standard of living in North East, Centre-West and South Europe during the Last 2000 Years. History of Meteorology. 2005;21:147-159.

5. UNDP. Human Development Report 2007/2008: Fighting climate change; Human solidarity in a divided world; 2007. Available:http://hdr.UNDP.org/en/reports/ global/hrdr

6. IPCC. Climate change: Impacts, adaption and vulnerability. Summary for policy makers. IPCC, 4th assessment report, International Panel on Climate Change, Cambridge University Press, Cambridge UK; 2007.

7. Suri T. Understanding farm-level technology adoption: Lessons learned from Cimmyt's micro surveys in Eastern Africa, CIMMYT Economics Working Paper 03-07; 2009.

Available:http://purl.umn.edu/46552

8. Sombroek WG, Braun $\mathrm{HMH}$, van der Pouw BJA. The exploratory soil map and agroclimate zone map of Kenya (1980) scale 1:1,000,000. Nairobi: Exploratory Soil Survey Report E1, Kenya Soil Survey; 1982.

9. FAO. Climate-smart agriculture: Policies, practices and financing for food security, adaptation and mitigation. Rome, Italy: Food and Agriculture Organization of the United Nations; 2010.

10. Grolink. Feasibility study for the establishment of certification bodies for organic agriculture in Eastern and Southern Africa. Report commissioned by Sida/INEC, Höje; 2002.

11. KNBS. Kenya population and housing census, population distribution by sex, number of households, area, density and county, Nairobi; 2009.

12. SPSS. Statistical package for the social sciences 14.0 for Windows 1989-2005 SPSS Inc. Chicago, Illinois; 2005. 
13. Foeken D, Owuor SO. Urban farmers in Nakuru, Kenya. Leiden/Nairobi: African Studies Centre /Centre for Urban Research. ASC Working Paper 45/2000; 2002.

14. Taylor A. Overview of the current state of organic agriculture in Kenya, Uganda and the United Republic of Tanzania and the opportunities for regional harmonization. UN; 2006.

15. Chavas JP, Posner JL, Hedtcke JL. Organic and conventional production systems in the Wisconsin Integrated Cropping Systems Trial: II. Economic and risk analysis 1993 2006. Agronomy Journal. 2009;101(2):288-295.

16. Darnhofer I, Lindenthal T, Bartel-Kratochvil $\mathrm{R}$, Zollitsch W. Conventionalisation of organic farming practices: From structural criteria towards an assessment based on organic principles. A review. Agronomy for sustainable development. 2010;30(1):6781.

17. Scialabba N. Factors influencing organic agriculture policies with a focus on developing countries. FOAM, 2000 Scientific Conference, Basel, Switzerland; 2000.

18. Makoba JW. Nongovernmental organizations (NGOs) and Third World development: An alternative approach to development. Journal of Third World Studies. 2002;19(1):53-63.

19. Saito KA, Mekonnen $H$, spurling $D$. Raising the productivity of women farmers in Sub-Saharan Africa. World Bank Publications. 1994;230.

20. Zelinski EJ. How to retire happy, wild and free: Retirement wisdom that you won't get from your financial advisor. Edmonton, $A B$, Canada: Visions International Publishing; 2010.

21. FAO. Assessment of the World Food Security Situation, CFS: 2007/2. Rome, Italy; 2007.

22. Kirkpatrick J. Farm succession research, trends and programs in Wisconsin. Paper presented to the Farm and Risk Management Education Conference, Reno, AZ, 31 M; 2009.

23. Shrum W. Science and story in development: The emergence of nongovernmental organizations in agricultural research. Social Studies of Science. 2000;30(1):95-124.

24. Farrington J, Bebbington $\mathrm{A}$, Wellard $\mathrm{K}$, Lewis DJ. Reluctant partners? Non- governmental Organizations, the State and Sustainable Agricultural Development; 1993.

25. Wellard K, Copestake JG. Nongovernmental Organizations and the State in Africa: Rethinking Roles in Sustainable Agricultural Development. London, UK; 1993.

26. Schwartz SH, Inbar-Saban N. Value self-confrontation as a method to aid in weight loss. Journal of Personality and Social Psychology. 1988;54(3):396-404.

27. Conroy WJ. Human values, smoking behaviour and public health programs. In Rokeach, M. (Ed.), Understanding Human Values: Individual and Societal, Free Press, New York, NY. 1979;199-209.

28. Ball-Rokeach SJ, Rokeach M, Grube JW. The great American values test: Influencing behaviour and belief through television. Free Press, New York, NY; 1984.

29. Allen MW, Baines S. Manipulating the symbolic meaning of meat to encourage greater acceptance of fruits and vegetables and less proclivity for red and white meat. Appetite. 2002;38:118-30.

30. Grube JW, Mayton DM, Ball-Rokeach SJ. Inducing change in values, attitudes, and behaviours: Belief system theory and the method of value self-confrontation. Journal of Social Issues. 1994;50(4):153-73.

31. Salasya BDS. Crop production and soil nutrient management: An economic analysis of households in western and central Kenya. PhD Thesis, Development Economics Group, Wageningen University, The Netherlands; 2005.

32. Mose LO, Kiiya WW, Powon MP, Omamo $B$, Kute C. The adoption of crop introductions for increased food supply and income in North-Rift Kenya. 2003;427-435. In: Mureithi, J. G. et al. (Eds.). Participatory technology development for soil management by small holders in Kenya. Proceedings of the 2nd Scientific Conference of the Soil Management and Legume Research Network Projects, KARI, Nairobi, Kenya.

33. Ngigi MW, Okello JJ, Lagerkvist CL, Karanja NK, Mburu J. Urban consumers' willingness to pay for quality of leafy vegetables along the value chain: The case of nairobi kale consumers, Kenya. International Journal of Business and Social Science. 2011;2(7 Special Issue): 208-216. 
34. Torquati B, Giacché G, Taglioni C, Musotti $F$. The effects of cap reform on the periurban agricultural area in the plain of the city of Assisi (Central Italy). In: 109th EAAE Seminar "The CAP after the Fischler reform: national implementations, impact assessment and the agenda for future reforms". Viterbo, Italy: EAAE, Universitia degli Studi della Tuscia, INEA, Europe Direct Lazio; 2008.

35. Mackenzie J, Whelan J, Oliver P. Reconnecting fragmented landscapes - A scoping study on natural resource and environmental management in the periurban landscapes of South; 2006.

36. IWM. Recycling realities: Managing health risks to make wastewater an asset. In: Water policy briefing. Colombo, Sri Lanka: IWMI; 2006.

37. Scott CA, Faruqui NI, Raschid-Sally L. Wastewater use in irrigated agriculture: Confronting the livelihood and environmental realities; 2004.

Available: $<|S|>: / / C A B \mid: 20043115021$

38. Duflo E, Kremer M, Robinson J. How high are rates of return to fertilizer? Evidence from field experiments in Kenya; American Economic Review. 2008;98:482-488.

39. Phelan PL, Mason JF, Stinner BR. Soilfertility management and host preference by European corn borer Ostrinia nubilalis on Zea mays L.: A comparison of organic and conventional chemical farming. Agriculture, Ecosystems and Environment. 1995;56(1):1-8.

40. Okello JJ, Swinton SM. From circle of poison to circle of virtue: Pesticides, export standards and Kenya's green bean industry. Journal of Agricultural Economics. 2010;(61):209-224.

41. Der Werf EV, Kariuki J, Onduru DD. Methodological issues in comparative agro-economic on-farm research assessments of organic versus conventional farming techniques. Biological Agriculture \& Horticulture. 1997; 14(1):53-69.

42. Diop J, van der Werf E, Onduru DD, Kariuki J. On-farm agro-economic comparison of organic and conventional techniques in high and medium potential areas of Kenya. Leusden, Netherlands and Nairobi, Kenya: ETC Netherlands and Kenya Institute of Organic Farming (KIOF); 1998.

43. Onduru DD, de Jager A, Gachini G. The hidden costs of soil mining to agricultural sustainability in developing countries: A case study of Machakos district, eastern Kenya. International Journal of Agricultural Sustainability. 2006;3:167-176.

44. Dimitri C, Greene C. Recent growth patterns in the US organic foods market. Agriculture information bulletin. 2000;777.

45. Oberholtzer L, Dimitri C, Greene C. Price premiums hold on as U.S. organic produce market expands (USDA Economic Research Services VGS-308-01); 2005.

46. Lockie S, Lyons K, Lawrence G, Mummery K. Eating 'green': Motivations behind organic food consumption in Australian Sociology Ruralist. 2002;42:23-40.

47. Williams PR, Hammitt JK. Perceived risks of conventional and organic produce: Pesticides, pathogens and natural toxins. Risk Analysis. 2001;21:319-330.

48. Iheke OR. Economics of homestead vegetable production in Abia State, Nigeria. Agricultural Society of Nigeria Proceeding of the 43rd Annual Conference held in Abuja, October, 20th- $23^{\text {rd }} .2009$; 305.

49. Bationo A, Mokwunye U, Vlek PLG, Koala $S$, Shapiro I. Soil fertility management for sustainable land use in the West African Sudano-Sahelian zone. In Grain Legumes and Green Manures for Soil Fertility in Southern Africa: Taking Stock Of Progress, Proceedings of a Conference (8-11 October, 2002), Leopard Rock Hotel, Vumba, Harare, Zimbabwe, Soil fertility Network and CIMMYT. 2003;253292.

50. Abdulrahman A, Yahaya A. Resource use efficiency of vegetable production in Kaduna State, Nigeria. Agricultural Society of Nigeria Proceeding of the 43rd Annual Conference held in Abuja. 2009;270.

51. Howden SM, Soussana JF, Tubiello FN, Chhetri N, Dunlop M, Meinke H. Adapting agriculture to climate change. Proceedings of National Academic of Science, USA. 2007;104(19):691-19:696.

52. USAID. Paradise lost? Lessons from 25 years of USAID environment programs in Madagascar. Washington, DC: U.S. Agency for International Development; 2010.

53. World Bank. Project Paper on a Proposed Additional Credit in the amount of SDR 18.5 million (US $\$ 30$ Million Equivalent) to the Republic of Madagascar for the Rural 
Development Support Project. Washington, DC: The World Bank; 2008.

54. National Academy of Sciences, (NAS). Climate change science: An analysis of some key questions. National Academies Press. 2001;42.

55. Solomon S. Climate change 2007-the physical science basis: Working group I contribution to the fourth assessment report of the IPCC. Cambridge University Press. 2007;4.

56. Intergovernmental Panel on Climate Change (IPCC). Working Group I Third Assessment Report. Cambridge University Press. Cambridge, UK. 2001;881.

57. Luseno WK. Assessing the value of climate forecast information for pastoralists: Evidence from Southern Ethiopia and Northern Kenya, World Development. 2003;31(9):1477-1494.

58. Dunn RR. Poetic entomology: Insects in Japanese haiku. American Entomology. 2000;46:70-72.

59. Kihupi $\mathrm{N}$, Kingamkono $\mathrm{R}$, Dihenga $\mathrm{H}$, Kingamkono M, Rwamugira W. Integrating indigenous knowledge and climate forecasts in Tanzania. In Coping with Climate Variability: The Use of Seasonal Climate Forecasts in Southern Africa; O'Brien, K., Vogel, C., Eds.; Ashgate Publishing Ltd.: Hampshire, UK and Burlington, VT, USA. 2003;155-169.

60. Orlove B, Roncoli C, Kabugo M, Majugu A. Indigenous climate knowledge in southern Uganda: The multiple components of a dynamic regional system. Climate Change. 2010;100:243-265.

61. Ziervogel G. Targeting seasonal climate forecasts for integration into household level decisions: The case of smallholder farmers in Lesotho. Geography Journal. 2004;170, 6-21.

62. Grothmann T, Patt A. Adaptive capacity and human cognition: The process of individual adaptation to climate change. Global Environmental Change. 2005; 15(3):199-213.

63. Grenzeback LR, Lukmann AT. Case study of the transportation sector's response to and recovery from Hurricanes Katrina and Rita. In: The Potential Impacts of Climate Change on U.S. Transportation. The National Research Council, National Academy of Science, Transportation Research Board and Department of
Earth and Life Sciences, Washington, D.C; 2008.

64. Pauchard A, Kueffer C, Dietz H, et al. Ain't no mountain high enough: Plant invasions reaching new elevations? Frontiers in Ecology and the Environment. 2009;7: 479-486.

65. Dale VH, Joyce LA, McNulty $\mathrm{S}$, et al. Climate change and forest disturbances. Biological Sciences. 2001;51:723-734.

66. Alpert $\mathrm{P}$, Bone E, Holzapfel C. Invasiveness, ability and the role of environmental stress in the spread of nonnative plants. Perspectives in Plant Ecology, Evolution and Systematics. 2000;3:52-66.

67. Allen CD, Breshears DD. Drought-induced shift of a forest-woodland ecotone: Rapid landscape response to climate variation. Proceedings of the National Academy of Sciences, USA. 1998;95:14839-14842.

68. O'Gorman PA, Schneider T. The physical basis for increases in precipitation extremes in simulations of 21st-century climate change. Proceedings of the National Academy of Sciences, USA. 2009;106:14773-14777.

69. Trenberth KE, Fasullo JT, D Kiehl J. Earth's global energy budget. Bulletin of the American Meteorological Society. 2009; 90:311-323.

70. Kaloki P. Sustainable climate change adaptation options in agriculture: The case of Chickpea in the Semi-Arid Tropics of Kenya; 2010.

71. Williams AP, Funk C. A westward extension of the warm pool leads to a westward extension of the Walker circulation, drying eastern Africa. Climate Dynamics; 2010. DOI: $10.1007 /$ s00382 $0100984-y$

72. Markowitz L. Finding the field: Notes on the ethnography of NGOs. Human Organization. 2001;60(1):40-46.

73. Thornton PK, Jones PG, Owiyo T, Kruska $R L$, Herrero $M$, Kristjanson $P$, Notenbaert A, Bekele N, Omolo A, with contributions from Orindi $V$, Ochieng $A$, Otiende $B$, Bhadwal S, Anantram K, Nair S, Kumar V, Kelkar U. Mapping climate vulnerability and poverty in Africa. Report to the Department for International Development, ILRI, Nairobi, Kenya. 2006;200.

Available:http://www.dfid.gov.uk/research/ mapping-climate.pdf 
74. Butt TA, McCarl BA, Angerer J, Dyke PT, Stuth JW. The economic and food security implications of climate change in Mali. Climatic Change. 2005;68(3):355-378.

75. Mihindo N. Organic agriculture in Kenya: fusion of science and traditional knowledge. In L. Guarino (ed.), Traditional African Vegetables: Promoting the Conservation and Use of Underutilized and Neglected Crops. Rome, Italy: International Plant Genetic Resources Institute. 1997; 96-97.

76. Madison D. The perception of and adaptation to climate change in Africa.
World Bank Policy Research Working Paper 4308. Washington, DC: The World Bank; 2007.

77. Heltberg R, Siegel PB, Jorgensen SL. Addressing human vulnerability to climate change: toward a 'no-regrets' approach. Global Environmental Change. 2009;19: 89-99.

78. Heltberg R, Siegel PB, Jorgensen SL. Addressing human vulnerability to climate change: Toward a 'no-regrets' approach. Global Environmental Change. 2009;19: 89-99. 


\section{APPENDICES}

1 Baseline Survey

Analysis of smallholder organic production systems in Kenya

\section{QUESTIONNAIRE}

\section{A) Identification}

Date of interview: Name of respondent: Name of the Enumerator: ..Questionnaire number:

County: Sub-county/District: Tel no: GPS Coordinates: Distance from Nairobi (BHR):

\section{B) Demographics and household characteristics}

\begin{tabular}{|c|c|c|c|}
\hline No & Questions & Coding categories & Skip to \\
\hline \multirow[t]{2}{*}{1} & Gender & Female: $\ldots \ldots \ldots \ldots \ldots \ldots \ldots \ldots \ldots \ldots \ldots \ldots \ldots \ldots \ldots \ldots \ldots \ldots \ldots \ldots$ & \\
\hline & & Male: .............. & \\
\hline \multirow[t]{5}{*}{2} & Position in the household & Household head: ..........................1 & \\
\hline & & 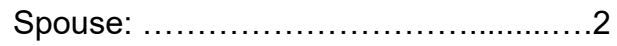 & \\
\hline & & 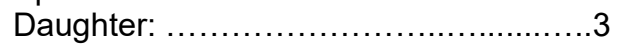 & \\
\hline & & Son: $\ldots \ldots \ldots \ldots \ldots \ldots \ldots \ldots \ldots \ldots \ldots \ldots \ldots \ldots \ldots \ldots \ldots \ldots \ldots \ldots \ldots \ldots \ldots$ & \\
\hline & & Other: (Specify) ............................ 5 & \\
\hline \multirow[t]{5}{*}{3} & Marital status & 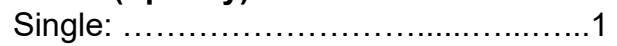 & \\
\hline & & Married: ..... & \\
\hline & & Divorced: .................................. & \\
\hline & & Widow/widower: ............................4 & \\
\hline & & Other:(Specify) ........................... 5 & \\
\hline 4 & Age & Age in years:...$\ldots \ldots \ldots \ldots \ldots \ldots \ldots \ldots$ & \\
\hline \multirow[t]{5}{*}{5} & Level of education & Less than primary: $\ldots \ldots \ldots \ldots \ldots \ldots \ldots \ldots \ldots \ldots \ldots$ & \\
\hline & & Primary: $\ldots \ldots \ldots \ldots \ldots \ldots \ldots \ldots \ldots \ldots \ldots \ldots \ldots \ldots \ldots \ldots \ldots \ldots \ldots \ldots \ldots$ & \\
\hline & & 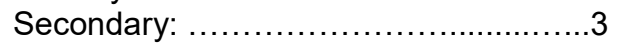 & \\
\hline & & College: .................................... 4 & \\
\hline & & University: ............................... 5 & \\
\hline \multirow[t]{3}{*}{6} & What is your occupation/source of & Farming: $\ldots \ldots \ldots \ldots \ldots \ldots \ldots \ldots \ldots \ldots \ldots \ldots \ldots \ldots \ldots \ldots \ldots \ldots \ldots \ldots \ldots \ldots$ & \\
\hline & income & Employed: .................................2 & \\
\hline & & Business other than farming: .............. 3 & \\
\hline
\end{tabular}

\section{Climate Change}

\begin{tabular}{|c|c|c|}
\hline 7 & $\begin{array}{l}\text { Have you ever heard of climate } \\
\text { change? }\end{array}$ & 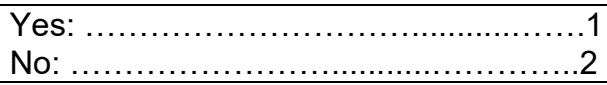 \\
\hline 8 & $\begin{array}{l}\text { If Yes ( } 1 \text { above), what is your } \\
\text { understanding of climate change? }\end{array}$ & 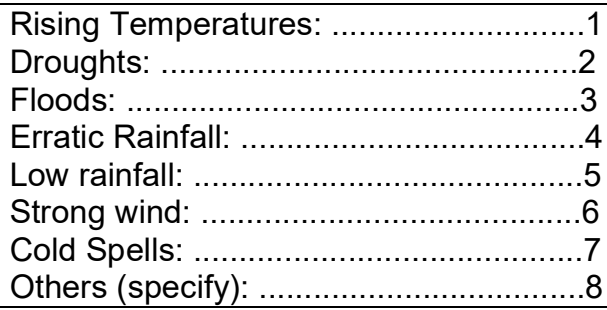 \\
\hline 9 & $\begin{array}{l}\text { How and where do you get } \\
\text { information on climate change from? }\end{array}$ & 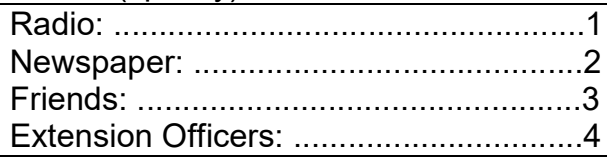 \\
\hline
\end{tabular}




\begin{tabular}{|c|c|c|}
\hline & & 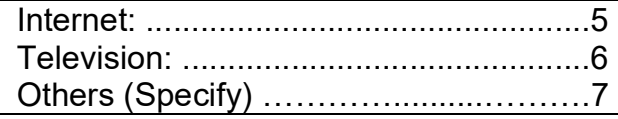 \\
\hline 10 & \multicolumn{2}{|c|}{ What in your opinion are the possible causes of climate change? Record detail } \\
\hline $11 a$ & \multirow{2}{*}{$\begin{array}{l}\text { Have you ever experienced/noticed } \\
\text { any changes in climate in your } \\
\text { locality? }\end{array}$} & Yes: $\ldots \ldots \ldots \ldots \ldots \ldots \ldots \ldots \ldots \ldots \ldots \ldots \ldots \ldots \ldots \ldots \ldots \ldots \ldots$ \\
\hline & & 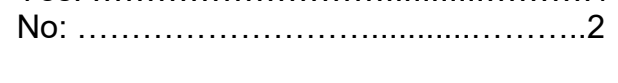 \\
\hline \multirow[t]{8}{*}{$11 \mathrm{~b}$} & \multicolumn{2}{|c|}{ If Yes in above, what changes have you experienced/noticed and since when? } \\
\hline & Change & $\begin{array}{l}\text { From When (Give years e.g. } 1990 \text { or } \\
\text { range of years e.g. from } 1990 \text { to } 1999 \text { ) }\end{array}$ \\
\hline & \multicolumn{2}{|l|}{ Erratic rainfall [ ] } \\
\hline & \multicolumn{2}{|l|}{ Low rainfall [ ] } \\
\hline & \multicolumn{2}{|l|}{ Flooding due to heavy rains [ ] } \\
\hline & \multicolumn{2}{|l|}{ Prolonged droughts [ ] } \\
\hline & \multicolumn{2}{|l|}{ Increasing temperatures [ ] } \\
\hline & \multicolumn{2}{|l|}{ Others (specify) .................... } \\
\hline \multirow[t]{3}{*}{12} & \multicolumn{2}{|c|}{$\begin{array}{l}\text { To what extent have the changes identified in 11a above impacted on } \\
\text { agricultural activities? }\end{array}$} \\
\hline & \multicolumn{2}{|l|}{ At your farm/local level } \\
\hline & \multicolumn{2}{|c|}{$\begin{array}{l}\text { Reduced crop yield [ ] } \\
\text { Change in planting time [ ] } \\
\text { Crop failure [ ] } \\
\text { Increased pest and disease infestation [ ] } \\
\text { Flooding of crop fields [ ] } \\
\text { Reduced soil moisture [ ] } \\
\text { Others (specify) ......................... }\end{array}$} \\
\hline 13 & \multicolumn{2}{|c|}{ How are you responding to these changes in $11 \mathrm{~b}$ above? Record detail } \\
\hline \multirow[t]{2}{*}{14} & \multirow{2}{*}{$\begin{array}{l}\text { Do you anticipate further changes in } \\
\text { climate in the near future? }\end{array}$} & 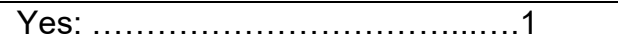 \\
\hline & & 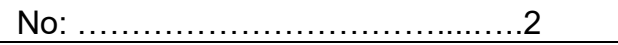 \\
\hline \multirow[t]{4}{*}{$15 a$} & \multirow{4}{*}{$\begin{array}{l}\text { If Yes in } 46 \text { above, in what timescale } \\
\text { do you expect these changes to } \\
\text { occur? }\end{array}$} & $0-5$ years: ..................................1 \\
\hline & & $5-10$ years: ................................ \\
\hline & & $10-20$ years: .............................. \\
\hline & & over 30 years: ...........................4 \\
\hline \multirow[t]{3}{*}{$15 b$} & \multicolumn{2}{|c|}{ Give reasons for choice of your time scale in (a) above. Record detail } \\
\hline & \multicolumn{2}{|c|}{ } \\
\hline & \multicolumn{2}{|c|}{ (1, } \\
\hline \multirow[t]{2}{*}{16} & \multicolumn{2}{|c|}{$\begin{array}{l}\text { What aspects of climate change do you anticipate to notice profound changes } \\
\text { and why? E.g. rainfall, floods, temperatures etc }\end{array}$} \\
\hline & Aspect/Change & Why \\
\hline 17 & \multicolumn{2}{|c|}{ How will you respond to the changes identified in 16 above? Record detail } \\
\hline & \multicolumn{2}{|c|}{ } \\
\hline
\end{tabular}




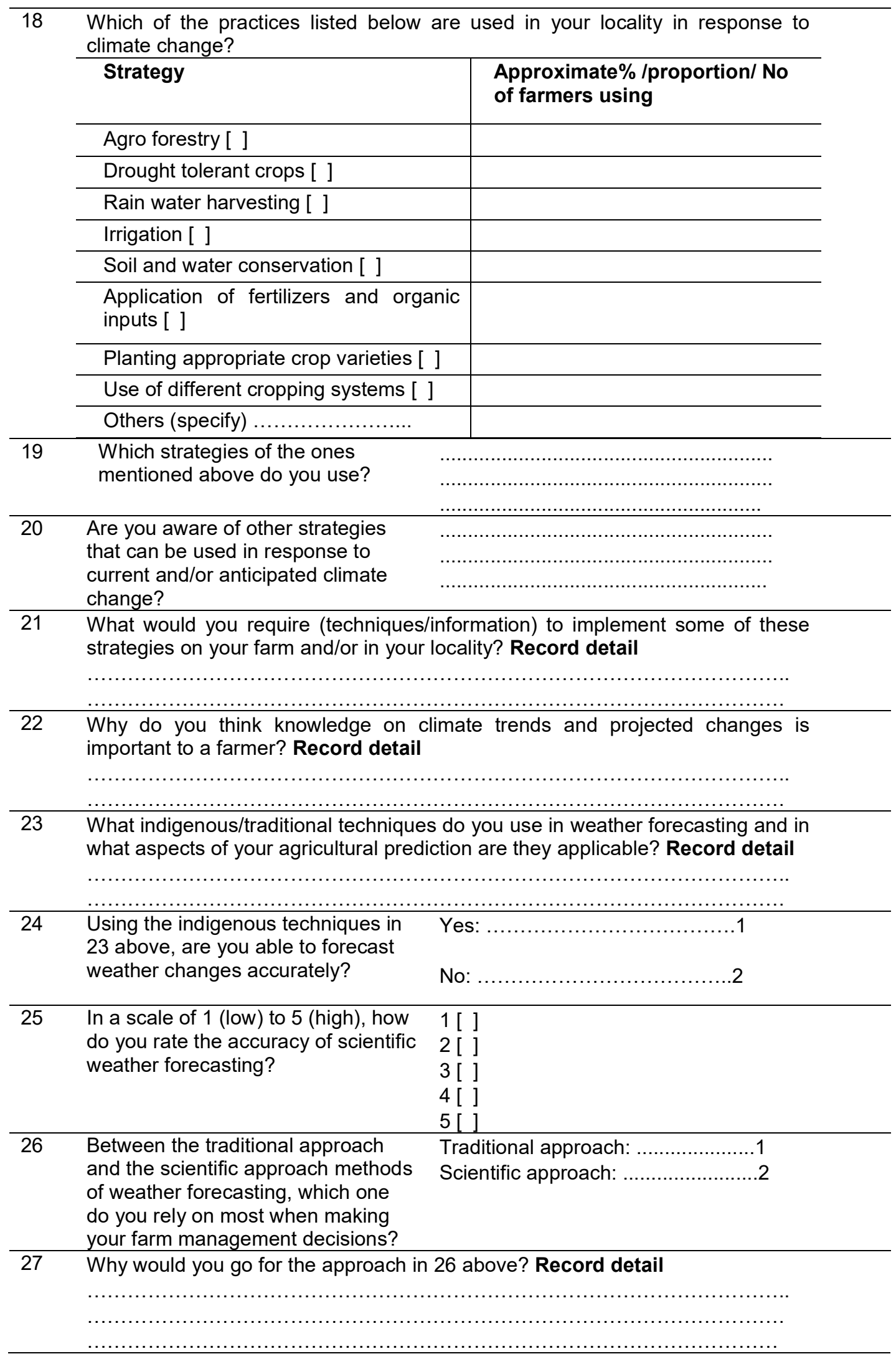




\begin{tabular}{|c|c|c|}
\hline 28 & $\begin{array}{l}\text { How do you rate the significance of } \\
\text { climate change as an issue in } \\
\text { agricultural production? }\end{array}$ & $\begin{array}{l}1 \text { [ ] Rated least } \\
2[\text { ] } \\
3[\text { ] } \\
4[\text { ] } \\
5 \text { [ ] Rated high }\end{array}$ \\
\hline 29 & $\begin{array}{l}\text { Who do you think should play a } \\
\text { bigger role in the mitigation of the } \\
\text { effects of climate change? }\end{array}$ & 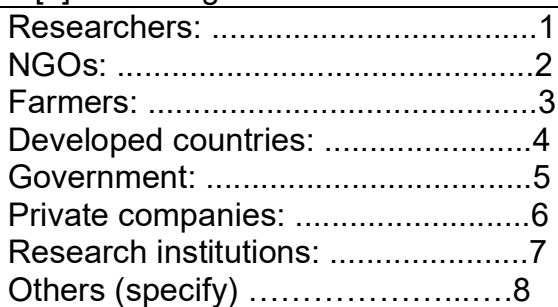 \\
\hline
\end{tabular}

Thanks for giving me an opportunity to interview you

(c) 2016 Ndukhu et al.; This is an Open Access article distributed under the terms of the Creative Commons Attribution License (http://creativecommons.org/licenses/by/4.0), which permits unrestricted use, distribution, and reproduction in any medium, provided the original work is properly cited.

Peer-review history:

The peer review history for this paper can be accessed here: http://sciencedomain.org/review-history/16838 